\title{
臨床研究
}

\section{5 歳以下の虫垂炎症例の検討}

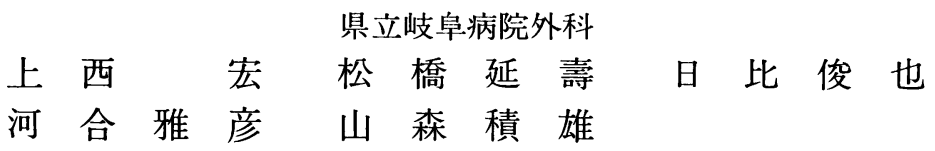

\section{Clinical Study on Appendicitis in Children under 6 Years of Age}

\author{
Hiroshi UENISHI, Nobuhisa MATSUHASHI, Toshiya HIBI, \\ Masahiko KAWAI and Tsumio YAMAMORI \\ Department of Surgery, Prefectural Gifu Hospital
}

27 年間に経験した 6 歳未満の虫垂炎症例24例のうちカタル性を除外した15例を検討した。(結果) (1) 2 歳以下で は全例が沉発性腹膜炎の診断で開腹されていた。(2) 3 歳以上では自覚的所見が不十分であっても，他覚的所見は 判断可能であることが多かった。(3)病恼期間が 2 日以内の群では全例術後入院期間が 7 日以内であったのに対 し, 病悩期間が 3 日以上の群では全例 10 日以上であった。

索引用語：急性虫垂炎 (Acute appendicitis)， 6 歳未満（Children under 6 years of age), 病悩期間（suffering period)

\section{はじめに}

5 歳以下の乳幼児虫垂炎は頻度が低く，その理 学的所見を正確にとらえることが困難であること より診断に苦慮することが多い。また乳幼児であ るため安易に手術に踏み切れず，手術適応の判断 が遅れる傾向にあり病状が進行している例が多 い。今回，5歳以下の虫垂炎症例における各年代 の臨床症状や経過を明確化し，問題点を検討した ので報告する。

\section{対象および方法}

27 年間における当科の急性虫垂炎手術症例は 1,081 例で， 5 歳以下の乳幼児症例は 24 例 $(2.2 \%)$ であった。このうち腸間膜リンパ節炎などの部分 症として発症した可能性のあるカタル性虫垂炎 9 例を除外し，化膿性 5 例，壊疽性 5 例，穿孔性 5
例の計15例を対象とした。年齢別では 1 歳が 1 例, 2 歳が 2 例, 3 歳が 3 例, 4 歳が 5 例, 5 歳が 4 例で, 病型別では化膿性, 壊疽性, 穿孔性が各 5 例であった。壊疽性および穿孔性虫垂炎の占める 割合は 1 ～ 3 歳で100\% (6 / 6 )， 4 歳で $60 \%$ ( 3 / 5 )，5歳で25\%（1/4）であった。穿孔率は順 に66.7\% (4/6)，20\%(1/5)，0\%(0/4) であった (Fig. 1)。男女別では男児 6 例，女児 9 例であった。この15例を年龄別, 病型別に分類し 臨床症状，経過を対比して検討した。以下有意差 の検定は 2 群間はStudent's t-test, Mann-Whitney testを, 多群間はKruskal-Wallis test, Scheffe’s Fを用いた。

\section{結 果}

\section{1 年齢別臨床症状の検討}

1) 主訴 
初診時に虫垂炎診断に重要な右下腹部痛を訴之 たのは 3 歳以下では皆無であり4歳児でも1例

(20\%)のみであったが，5歳巟では 3 例 (75\%) が訴えることが可能であった。3歳以下では発熱, 嘔吐が主症状であり，漠然とした腹清を訴える程 度にとどまっていた。男女差は明らかでなかった

(Fig.2)。ちなみに初診時に虫垂炎を疑われたの は 5 歳児では $100 \%(4 / 4)$ であったのに対し, 4 歳以下では $27.3 \%(3 / 11)$ にととまり, 全体で は $46.7 \%(7 / 15)$ であった。

\section{2) 理学的所見}

右下腹部圧痛は 3 歳以上では $83.3 \%(10 / 12) に$ 認められた。Blunberg徵候は 4 歳以上では88.9\%

(8/9)が陽性であった。また筋性防御は 3 歳以

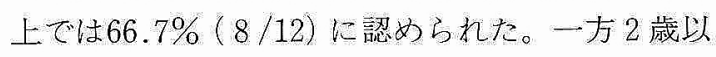

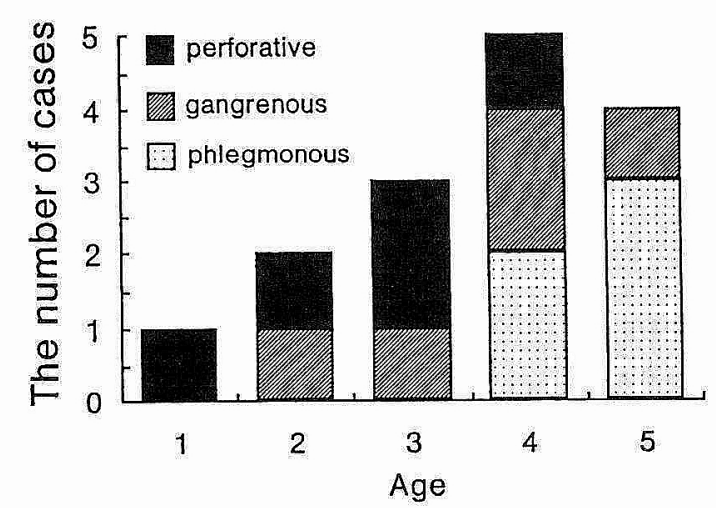

Fig. 1 The number of cases of appendicitis by ages (without catarrhal type)
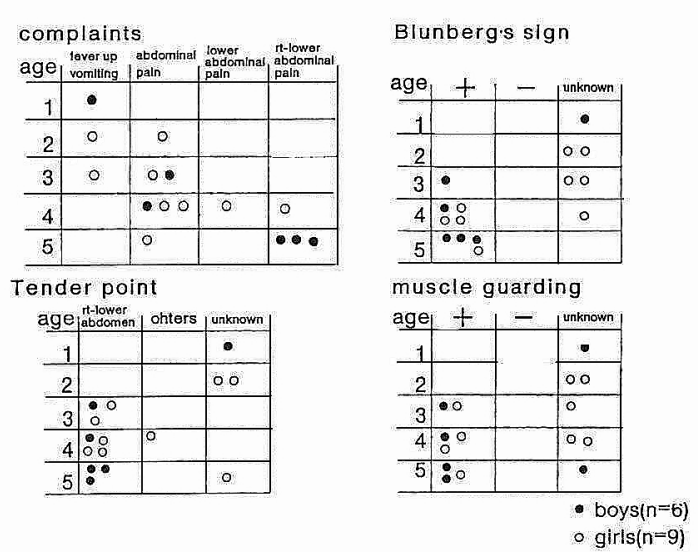

Fig. 2 Preoperative findings in different age groups
下ではこれらの所見を全くとらえることができ ず，腹部膨隆が唯一の所見であった。また男女差 は明らかでながった（Fig.2)。

\section{2 腹部単純 X線所見}

niveauは 2 歳以下で $100 \%(3 / 3), 3$ 歳で66.7 \% (2/3)に認められたが，4歳以上では認めな かった。

\section{3 術前末梢血白血球数と体温}

末梢血自血球数 (以下WBC), 体温 (以下BT) とも病型間に抺いて一定の傾向を示さず, 有意差 も認めながった。かし化膿性虫垂炎ではWBCが $12,000 \sim 16,000 / \mathrm{mm}^{3}$ 以内の範囲に集中していた のに対し，壊疽性亏よび穿孔性虫垂炎では 10,000 / $\mathrm{mm}^{3}$ 以下から $30,000 / \mathrm{mm}^{3}$ 以上と症例間のばらつ きが大きかった (Fig.3A)。BTも同様の傾向を示 し, 化膘性虫垂炎では37.2 -38.3 $3^{\circ} \mathrm{C}$ 範团であっ たのに対し，壊瘨性子よび穿孔性虫垂炎では症例 間に $2{ }^{\circ} \mathrm{C}$ 以上の較差が認められた（Fig.3B）。

\section{4 経過時間の年齢別検討}

1) 発症から初診までの時間：全体では 5 -48時 間，平均 $19.2 \pm 15.2$ 時間であった。 5 歳児では全 例が24時間以内に来院していたが，4歳児では数 時間で来院した例と 24 時間以上を要した例に 2 分 され，3歳以下では大多数が24時間以上を要して Wた (Fig.4A)。

2) 初診から手術までの期間：全体では 0 １5日

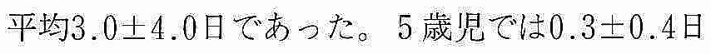
で全例が24時間以内であったが，4歳以下では
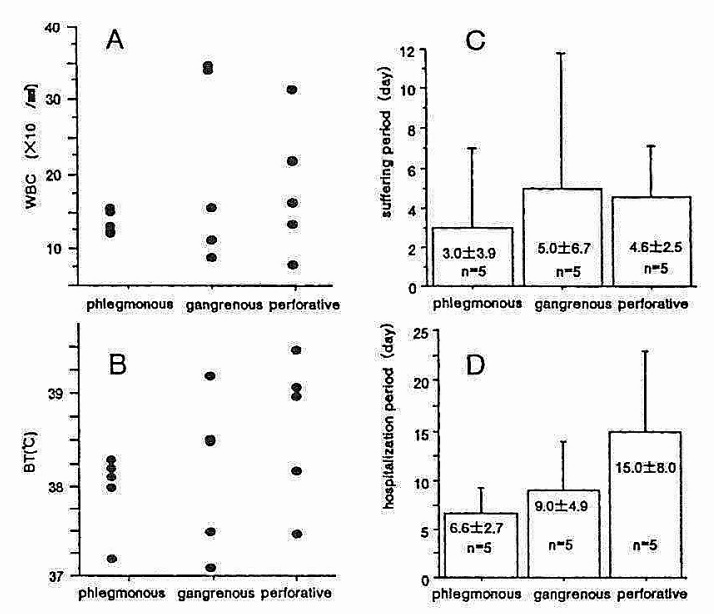

Fig. 3 Comparison among types of appendicitis 

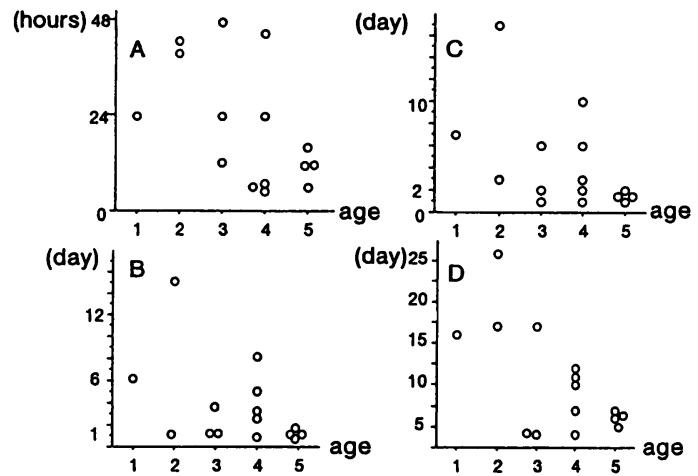

Fig. 4 The relationship between age and clinical course of the disease

$A$; the period from onset to first medical examination

$B$; the period from first medical examination to operation

$C$; sufferig period $(A+B)$

$D$; postoperative hospitalization period

$4.0 \pm 4.3$ 日で $63.6 \%(7 / 11)$ が24時間以上であっ た (Fig.4B)。

3 ) 病悩期間 $(A+B)$ ：発症から手術までの病悩 期間は，全体では 1 〜 17日（24時間以内は 1 日と 換算), 平均 $4.2 \pm 4.3$ 日であった。 5 歳児では $1.3 \pm$ 0.4 日で全例が 2 日以内であったが, 4 歳以下では $5.3 \pm 4.6$ 日で63.6\%（7/11）が 3 日以上であった (Fig.4C, 6A)。

4 ）術後入院期間：術後入院期間は，全体では 4 〜26日，平均 $10.2 \pm 6.2$ 日であった。 5 歳児では $6.3 \pm 0.8$ 日で全例が 7 日以内であったが 4 歳では

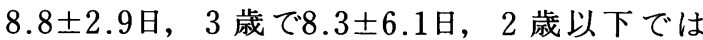
$14.0 \pm 7.8$ 日と低年齢児ほど延長する傾向であっ た (Fig.4D)。

\section{5 病型と経過時間との関連}

1 ) 病悩期間

病型別に病悩期間を検討すると，化膿性3.0土 3.9 日，壊疽性 $5.0 \pm 6.7$ 日，穿孔性 $4.6 \pm 2.5$ 日 と病 型間で有意差は認めなかった。2 日以内の穿孔例 が 1 例存在した $($ Fig.3C, 6B)。

\section{2 ）術後入院期間}

病型別に術後入院期間を検討すると，化膿性 $6.6 \pm 2.7$ 日，壊疽性 $9.0 \pm 4.9$ 日，穿孔性 $15.0 \pm 8.0$ 日と病状の進行とともに延長する傾向であった
A

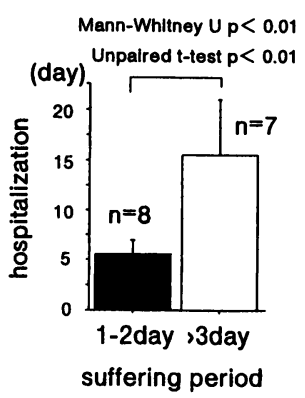

Fig. 5 The relationship between suffering period and postoperative hospitalization period (1)
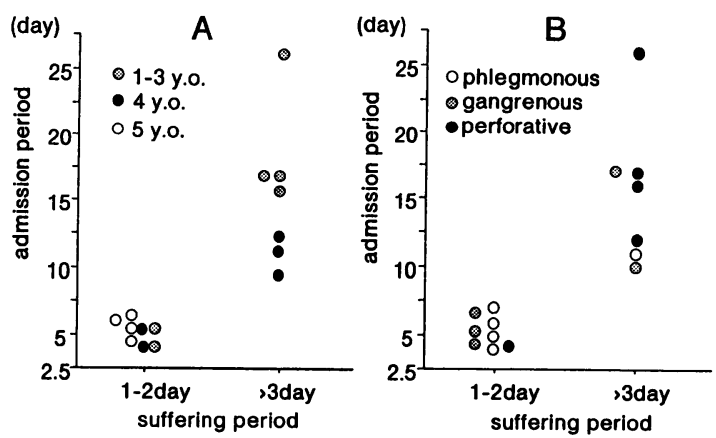

Fig. 6 The relationship between suffering period and postoperative hospitalization period (2)

が，病型間で有意差は認めなかった（Fig.3D）。

\section{6 病恼期間と術後入院期間との関連}

病悩期間が 2 日以内の 8 例では術後入院期間は $5.5 \pm 1.4$ 日で全例が 7 日以内であった。一方病悩 期間が 3 日以上の 7 例では $15.6 \pm 5.4$ 日で全例が 10 日以上の入院を要し，この 2 群間に有意差を認 めた (Fig.5A)。さらに病悩期間が 3 日以上の 7 例 を，病恼期間が 3 日の 2 例と 4 日以上の 5 例に分 け入院期間を検討したが，両群間に差を認めなか った $(\mathbf{F i g} .5 \mathrm{~B})$ 。また，この15例を年齢別，病型別 に分類し病悩期間と術後入院期間を検討すると, 年齿，病型に関係なく病悩期間が 2 日以内の症例 は入院期間が短期間であった。穿孔例であっても 2 日以内に手術した例では術後入院期間が 5 日で あり，逆に化膿性あるいは壊疽性虫垂炎であって も 3 日以上の経過例では 10 日以上の術後入院を要 した (Fig. 6$)$ 。 


\section{考察}

乳幼児期の虫垂炎は発生頻度が低く, 自覚症状 や他覚的所見を明確にとらえることが困難である ため診断および手術が遅れる傾向にある。乳幼児 といっても，年少児と年長児とでは臨床経過が著 しく異なると考えられるため年齢別に臨床症状を 検討した。その結果, 2 歳以下では腹痛の有無さ え不明なことが多く, 理学的所見も正確にとらえ ることは困難であった。そして腹部膨隆や単純X 線でのniveauといった沉発性腹膜炎の所見が開 腹の決め手となっていた。 $3 \sim 4$ 歳では自覚症状 を訴之る能力は個人差が大きく判断には苦慮する ものの, 圧痛や筋性防御などの理学的所見は比較 的正確に評価可能であった。 5 歳児になると, 右 下腹部痛として訴えることが可能となり, 理学的 所見も正確にとらえることができた。佐藤ら ${ }^{1)}$ 報告では 6 歳未満の虫垂炎51例のうち右下腹部痛 を訴えた児はわずか $7 \%$ であり，またGrosfeld ${ }^{2} に$ よると 2 歳以下の虫垂炎32例中Blunberg徵候が 証明されたのは半数にすぎなかったという。やは り乳幼児特に年少児では自覚症状や理学的所見か ら虫垂炎を疑うことはかなり困難であると考えら れた。乳幼児虫垂炎診断の困難性は経過時間にも 反映されており, 発症から来院までの期間, 初診 から手術までの期間，また両者を併せた病悩期間 とも年少児ほど長時間を要するという結果であっ た。 4 歳以下において発症から初診までは全例 48 時間以内であったにもかかわらず，初診から手術 までの期間は平均 $4.0 \pm 4.3$ 日を要しており，特に 理学的所見はかなり把握可能であるはずの 3,4 歳児が来院後も相当数経過観察されていた。この 理由として患児の発達程度の個人差という要因の 他に診察医の乳幼児虫垂炎診断に対する慣れとい う要因が考えられた。また当院でも内科的疾患の 部分症として発症することの多いカタル性虫垂炎 は切除を回避するよう心がけており,これも経過 観察される例が増加した一因と推察された。やは $\eta$ 自覚症状が不明確な 4 歳以下では, 理学的所見 のみで手術に踏み切るには限界があると推察さ れ, カ夕ル性虫垂炎を除外する意味でも超音波診 断 (以下US) 併用の重要性 ${ }^{3) 4}$ が示唆された。また,
虫垂炎の参考所見として重要なWBCおよびBT について検討したところ, 両者とも化膿性虫垂炎 においては比較的ばらつきが少なかったが, 壊疽 性あるいは穿孔性虫垂炎においては一定傾向を認 めず，診断の指標にはなりにくいものと考えられ た。むしろこれらの異常高値や低値は諸家の報 告 ${ }^{5) 6}$ にみられるごとく虫垂炎の重症度を反映す ると考之られた。さて早期診断が術後経過を良好 にすることは自明の理であるが, 病悩期間と術後 入院期間との関係を検討した結果もそれを如実に 反映していた。すなわち病悩期間が 2 日以内の群 では全例入院期間が 7 日以内であったのに対し て，3 日以上で手術を行った群では全例入院期間 が10日以上で両群間で有意差を認めた。穿孔例で も発症より 2 日以内に手術を行った例は術後 5 日 で退院可能となっており, 化膿性あるいは壊疽性 でも発症より 3 日以上で手術した例では 10 日以上 の入院を必要としていた。穿孔によって合併症が 増加し入院期間が延長するとの報告は多数みられ るが(1)6) 8), 柴田ら ${ }^{9)}$ は乳幼児虫垂炎の穿孔は発症 より2 日以内におこることが多いものの穿孔早期 のものは治療成績が良好であると述べ第 2 病日の 重要性を強調している。今回の検討でも穿孔の有 無だけでなく病悩期間すなわち炎症の波及した範 囲や持続時間が術後経過に大きく影響を及ばすと 推察され, 発症から 2 日以内に手術を行うことが 最も重要だと考えられた。

\section{結語}

乳幼児虫垂炎では，年少児と年長児とで臨床経 過が大きく異なっていた。乳幼児虫垂炎の早期診 断は容易ではないが第 2 病日を念頭に置いた診断 治療が重要と考えられた。

\section{参考文献}

1）佐藤典宏, 上田祐滋, 河野竜二他：乳幼児期急性 虫垂炎症例の臨床的検討. 宮崎医師会誌19：4044, 1995

2) Grosfeld JL, Weinberger M, Clatworthy HW $\mathrm{Jr}$ : Acute appendicitis in the first two years of life. J Ped Surg $8: 285-293,1973$

3) Rubin SZ, Martin DJ : Ultrasonography in the 


\section{5 歳以下の虫垂炎症例の検討}

management of possible appendicitis in childhood. J Ped Surg 25 : 737-740, 1990

4）池田正孝, 龍田正䢐, 里見 隆他：急性虫垂炎に 対する超音波検查の有用性の検討. 日臨外医会誌 $55: 2755-2763,1994$

5）小池能宣, 馬場栄次, 米山重人他：小児虫垂炎の 診断一とくに穿孔例の検討一. 北海道外科誌 33 : 64-68, 1988

6）白岩邦俊, 八木 実, 安孫子正美: 10年間の小児 急性虫垂炎手術例の検討. 太田病年報 $26: 39-50$,
1991

7）岡田賢三，松村敏信，岩坂尚仁他：当院における 最近 5 年間の小児虫垂炎について. 愛媛病会誌 $21: 1-3,1985$

8）瀬戸口正幸, 仲宗根朝紀, 横田美登志他：当院に おける過去10年間の小児虫垂炎手術例の検討一 特に 5 歳以下の症例について一. 佐世保病医業 $9: 159-162,1982$

9）柴田栄次郎：急性虫垂炎. 救急医21：286-287, 1997 